\title{
Engineering students' perception towards Malaysian nationhood course
}

\author{
Khairunesa Isa ${ }^{1}$, Wan Hanim Nadrah Wan Muda ${ }^{2}$, Abd. Rahman Ahmad ${ }^{3}$, Rosman Md. Yusoff ${ }^{4}$ Zulida Abd \\ Kadir $^{5}$ \\ 1,2,3,4,5 Universiti Tun Hussein Onn Malaysia, 86400 Parit Raja, Batu Pahat, Johor \\ Malaysia \\ *Corresponding author E-mail: nesa@uthm.edu.my ${ }^{a}$
}

\begin{abstract}
University students are among those who are responsible in setting the goals of national development. Therefore, they should possess good values in which portraying their personal identities, thus reflects the multiracial culture of Malaysia. However, a number of incidents such as the issue of National Anthem (Negaraku), AUKU conflicts, campus political extremes, gangsters', conflict of identity and so on do ruin their images as the ones who are intellectuals. This condition leads to the question of students' nationalism, particularly engineering students, where they are more concentrating on their technical courses compared to university requirement courses. This research was a survey designed research. The objectives of the research were (i) to determine the engineering students' level of appreciation towards Malaysian Nationhood course, (ii) to determine students' perception towards Malaysian Nationhood course, and (iii) to identify the students' preferences on university courses. A total of 200 students were randomly selected as the respondents of the research. The frequencies and percentages were analyzed using descriptive analysis. Findings showed that the engineering students' level of appreciation towards the Malaysian Nationhood course was at moderate level as they perceived the attendance to the course was mandatory Almost students agreed that they would not enroll in the course if they were given the choice. Overall, it showed that the students attended the class as it was a compulsory course set by the ministry. The findings portrayed the students' nationalism. Based on these findings, it is suggested that a more comprehensive modules and approaches which fulfill the needs of students should be prepared in order to emphasize the importance of nationalism among the students.
\end{abstract}

Keywords: Nationalism; Nationhood; Engineering Students' and Multicultural

\section{Introduction}

Universiti Tun Hussein Onn Malaysia (UTHM) is one out of four Malaysian Technical Universities (MTUN) in Malaysia. The focus of MTUN is to educate and train the students in preparing them to contribute their expertise to the industry, thus being the main catalyst to achieve the status of high-income country. Even the university shares the same objectives with other MTUN universities, UTHM wants its products to be balanced in various fields not only in the context of industrial and engineering but also possessing the love spirit to the country.

Due to this commitment, the university takes the initiative by instructing the students to enroll in several compulsory courses such as Entrepreneurship, Ethnic Relations, Nationalism and Contemporary Development in Malaysia, Co-curriculum, foreign language courses and some other courses as a requirement before graduation. Students are obliged to attend all the courses as these courses are not only meant to provide added values to the students themselves but also are believed to improve the students' quality in order to meet the requirements of the job market.

Each course offered has its own goals and objectives. For example, the Nationalism and Contemporary Development in Malaysia courses aim to produce good citizens, responsible and able to appreciate or understand the country's development. This goal clearly demonstrates the commitment of the university as one of the efforts to create world-class engineering students who are aware and appreciate the development and independence achieved by the country.

Today's generation especially the students, need to show their appreciation or understanding of the independence and development of Malaysia. By offering the courses such as Nationalism and Contemporary Development in Malaysia, it has seen as a move by the government and universities in giving exposure to students regarding the history and background of Malaysia. Students not only get to know the early history of Malaya and Malaysia but the process of its formation, the components and functions of government, the constitution, the development policies and current issues, which are discussed in the class. According to Abdul Aziz Abdul Rahman et al., (2015) patriotism will affect student's discipline, proud to be Malaysian and loyal to country and this will show how important patriotism affects the students' development.

\subsection{Problem Statement}

A good and responsible citizen should know the background and history of his country, race and the culture of the nation. History needs to be known, understood and appreciated by all citizens so that the citizens will be able to maintain the harmony and proud with what has been achieved today. The reason why the students need to enroll in courses such as Nationalism and Contemporary Development in Malaysia is to ensure that they will be able to 
continue the legacy of national development and independence gained. In addition, when the students appreciate or understand the history of the country such as offered by Nationhood course, they are able to educate their souls to have a positive attitude, high moral values, loyal to the country and fellow citizens, patriotism, and willing to sacrifice for the country. Through such trainings, students are also expected to appreciate the country's sovereignty and the independence will be preserved. However, students today are found to be less interested in the courses offered, such as Nationalism and Contemporary Development in Malaysia. Students are also found to be less sensitive to the government's efforts in maintaining its independence and implementing national development.

Lack of appreciation or understanding regarding the value of independence and national development drag students to involve in unhealthy activities. Students are also not aware of the facilities provided by the government. This shows the student's thinking is deteriorating in appreciating what they have. These actions seem to indicate that they are not grateful for what have been obtained through independence.

In addition, there are times when students are too vocal about an issue without analyzing the facts. They are also questioning the AUKU and refuse to serve in the country after completed their studies abroad.

Therefore, it is not surprising that most of the students do not know some basic concepts and facts such as the early history of Malaya, the concept of the Social Contract, Jus Soli and also the Dasar Pecah dan Perintah which are introduced by the British. There is no doubt when there are also students who do not know much about Federal Constitution such as what being stated in Article 3, Article 152, and Article 153. Even more distressing, there are also students who do not recognize or know the names of the Cabinet Ministers as well as the Chief Minister of the Malaysian states in Malaysia.

In this context, the question that arises is how the students would continue the legacy of development and maintaining the independence if they do not know the basics requirements in managing and planning the development and national security. In addition, to what extent they possess the elements of patriotism, personal values, and love to the country as they are labeled as the future leaders? Do they enroll in these subjects for the purpose of meeting the requirement of the university and improving their GPA? Therefore, the objectives of this study were to: -

i. determine the level of understanding among engineering students regarding the Nationalism and Contemporary Development in Malaysia courses

ii. determine their perceptions towards Nationalism and Contemporary Development in Malaysia courses; and

iii. identify the preferences of students to the courses offered at the university.

\section{Literature Review}

Malaysia is a multiracial country. To show this country's true patriotism, the locals have dubbed many things including providing several academic subjects at higher education such as Malaysian Studies, Ethnic Relations and National Language that have been implemented in universities' courses in order to achieve a balance knowledge in life. One of the main goals in implementing the Nationhood course is to let the new generation knows the struggles of the former leaders who have contributed much to bringing independence to the country and it is indirectly cultivated patriotic spirit in the lives of young people today. In fact, the Nationhood courses also allows students to learn about the background, political and social influences and civilization of the people. All ethnic groups in Malaysia have the same responsibilities to defend the sovereignty and independence of the country. Therefore, in order to maintain and carry the responsibilities, each individual should have the feeling of integrity and patriotism to the country as well as possessing national identity. The main goal of the Nationhood education is to instill the sense of loyalty, patience and passion into the nation. However, previous findings show that there are a mixture results on the value national identity of each ethnic in Malaysia and past practical evidences show that many students have a lack of interest to learn such subjects.

A study conducted by Othman et al. (1) shows that the national identity of Indians is much better than Malays. In addition, the Chinese proved to have the lowest national identity. This creates worries to the leaders as well as the academicians as it is believed that the Malays is known as the natives of Malaya. Besides, despite various attempts by the nation's leaders to unite its diverse people, Malaysians have grown more contrary over the years resulting in the citizens' failures to subscribe to a shared identity. Based on these findings, the question arises; what are the reasons for the Malays to have lower level of national identity and how do they lead the country in the future? How far is the appreciation of the present and new generation towards the history of the country itself?

The national identity is very important because it influences the actions and thoughts of individuals to the government, security and development of the country. Besides, the importance of $\mathrm{Na}$ tionhood education can be seen throughout the national philosophy known as Rukun Negara and the Constitutional Law. McKenzie (2) states that Nationhood education is important not only for its effects on politics and government, but also in relation to community and voluntary activities, social and international harmony. Through such an approach, the students will be gaining facts and understanding of the history of the tribe, the history of the region, the country and for the accumulation of the history of the national identity such as the flag and National Anthem song. However, less studies were conducted on the issue of national identity. More strategies and research needs to be created and done in getting more factual and robust empirical data and actions should be taken in preventing individuals from the negative elements. One of the common strategies to promote good citizens is through Nationhood course and curriculum either at a school level or higher degree level.

Unit Khas Utusan Malaysia in 2010 has conducted a survey on 200 respondents of which $89.5 \%$ of the total respondents aged between 15-30 years. Findings show that the teenagers are displaying a marked lack of knowledge about Malaysia history, the issue of Nationhood, and the aspects of patriotism. Besides, from a study that was done by Awang et. al (3), students do not like to attend classes and are not punctual for the Nationhood classes. Due to lack of interest in learning Malaysian Nationhood courses, most of the students are not active in class and do not perform revision and preparation before attending the class. Accordingly, this attitude will affect the ability of mastering the subject. Furthermore, there may be some of the new generation who celebrate Independence Day soullessly without knowing the true meaning of independence. Based on that study, the question arises; to what extent the effectiveness of the education system in this country particularly through the course of history or general education in order to insinuate the aspect of patriotism among Malaysians?

Another study was done by Isa \& Ani (4) among engineering students at UTHM. She found that the engineering students' understanding regarding the formation of Malaysia Day was at a moderate level ( $\min 2: 40$ ). The findings also show that the engineering students are not focusing on matters related to the country. Khairunesa findings (2011) support Adam (5) study where he finds that Malaysian students are less exposed to the basic concepts of Malaysia history, including the formation of Malaysia and the concept of the nation state. Some studies revealed that the Malaysian Studies have been given less priority by most students. As a result, most students gained low marks for this subject which simultaneously affects their academic cumulative grade points. Extensive past studies suggest that there is a close relationship between students' attitudes towards academic subject and their overall achievement (6). Furthermore, a study of academic achievement carried out by Ariffin (7) focused on individual's learning style and how it affects his/her academic achievement. 
Students who have negative attitudes towards education activities are found to carry complicated behaviour including anti-social and off-task behaviour (8).

However, personal values, patriotism and the spirit of love for the country are deteriorating not only for engineering students but also students from other disciplines (1). This is not only occurred in Malaysia, but in other parts of the world too. Reviews by (9) on 795 respondents in two age cohorts find that older generation in the country has the German patriotism, national identity and ethnocentrism higher than the younger generation. This is because the old generation still holds the philosophy of "biar putih tulang asalkan jangan berputih mata". That is why they are willing to curl up in jail solely to fight for independence. In other words, their patriotic spirit cannot be replaced. The same question also can be posed: how the younger generation will lead the country in the future?

\section{Methodology}

The present study was conducted on 200 students (semester one to semester four) who are in engineering courses (electrical, mechanical, civil and information technology). The respondents were randomly selected among students who enrolled in Nationalism and Contemporary Development in Malaysia courses. Students involved in this study were Malay students. The questionnaire with four sections was used as the instrument of the study. The data were analyzed using SPSS 14.0. Distribution of frequencies and percentages were analyzed using descriptive statistics.

\section{Findings and Discussions}

The results will be presented according to the research objectives:

i. To determine the level of understanding among engineering students towards the Nationalism and Contemporary Development in Malaysia courses.

The findings showed that the level of student understanding was at a moderate level (mean 2.50). These findings could indirectly lead to students' perceptions whether they were really appreciating or understanding the history and national development or just memorizing for the examinations. It was evident that the students were not able to answer the basic concepts of the course when the students met the lecturer on the following semester. These questions have been asked during the final examination for the previous semester. It could be concluded that the students memorized the facts just for the purpose of final examinations in helping them to obtain good GPA.

ii. To determine students' perceptions towards the Nationalism and Contemporary Development in Malaysia courses The analysis found that $80 \%$ of the students attended the lectures of Nationalism and Contemporary Development in Malaysia courses just for the purpose of their attendances, not because of their willingness to learn and gain something new about the subjects. Most students said they only presented to the class because the courses were the university requirement subjects or else they would not enroll in these courses.

This finding was supported by the issue when a small group of students prioritized other courses or lecturers who conducted the quizzes, tests, exhibitions, and seminars during lectures of Nationalism and Contemporary Development in Malaysia courses. This showed that the students underestimated the value of the Nationalism and Contemporary Development in Malaysia courses because they felt these courses did not have a significant relationship with their careers as future engineers. If this continues, what will happen to their national identity? Where is the spirit of patriotism, love and willingness to sacrifice for the country? How they are going to govern the country if the national identity does not exist?

iii. To identify the students' preferences to courses offered

The results further showed that almost $95 \%$ of total students stated that they would not take the Nationalism and Contemporary Development in Malaysia courses if they were given the choice as they preferred the engineering courses only. They did not have the initiative to know or get the idea what they were going to learn throughout the semester as nearly $80 \%$ of students did not know directly what they would learn.

This made the students trapped in the situation where they did not know basic things related to the history and development of the country such as the Social Contract, the basis of the National Principles and Article 153 of the Constitution. The question is how the students today are going to determine the direction of the State government and if they do not know much about the country? How to determine any policies, any rights or limitations if they have less knowledge about Article 153?

These findings gave a very serious picture regarding the students' perceptions on the Nationalism and Contemporary Development in Malaysia courses where almost $75 \%$ of the course content was discussing the history and the formation of Malaysia, and matters involving policy, administration, and governance components.

As the Nationalism and Contemporary Development in Malaysia courses were not the choices of the students, this could be analyzed or viewed from different perspectives. What are the factors that lead to this issue? Is that because of the lecturers? Or is it because the students claimed that they received less exposure? If they claim they are lacking of exposures, this is not true as they are exposed to national identity during their secondary school.

\section{Conclusion}

It can be concluded that the Malay first year engineering students possess a moderate level of national identity. Most students have the idea or know the fundamental concepts of Malaysia development and the independence date, the names of the five prime ministers and the origin of the name of Malacca. The other concepts or matters that are less featured are the establishment of Malaysia Day, the role of the New Economic Policy and the principles of Vision 2020, where the students are unable to explain them clearly. Even this has seen as a trivial, it gives a significant impact on the identity construction and patriotism. It will also affect the growth and development of the country. Students are also unable to distinguish between the dates of Independence Day and Malaysia Day. They are also unable to remember the correct order of Rukun Negara.

The incident of May $13^{\text {th }}$ and Kampung Medan as well the growing number of demonstrations performed by graduates, are among the issues that we should think of. In this context, all citizens at all levels should pay attention and support to the students, especially the Malay students, so that they can understand, remember and appreciate the most important achievement happened in the country.

The Malay students' understanding for the country independence has a significant impact on the development of students' personalities. Other than that, the national identity is also important as the students can uphold the independence obtained. Lack of national identity can cause a student unable to defend the sovereignty and independence of the country.

The strength of a nation is the combination of the government and the people's strengths. The government requires the people to support the policies that have been established. If the students do not understand the goals and direction of our national leaders or less sensitive to the history of the country, this may open up the possibilities for others to depress us. For example, how people try to destroy the national flag, thus this provokes the Malaysian. Other than that, questions regarding the provisions of Malaysia Constitution are often raised by several individuals in the Malaysian society itself. It is crystal clear that some people or individual try to mock this social contract that has been agreed from the very beginning. In this context, if a student or young Malays are not aware of the history of the Federal Constitution, it is possible if they become leaders and will allow some changes for natives of Sabah and Sarawak. Thus, the natives of Sabah and Sarawak will 
eventually lose their rights and privileges as indigenous people of Malaya.

Students should aware of their role to the country. It is important to ensure the continuality of sovereignty and independence of the country, as well as the Malaysia Constitution. This can only be realized if students are really understand and know the history of liberty, civilization and the formation of nation. With that, the students will realize the importance of the Nationalism and Contemporary Development in Malaysia courses. Students must realize that even though they enroll in courses which are not related to engineering, this is important for them to have some basic knowledge about their country.

Besides the students, other parties such as lecturers, university or the ministry, should seriously put on focus on this matter. As a lecturer, they should have the best approach when delivering the lectures especially for engineering students. Many approaches can be used in the process of teaching and learning, such as using PBL approach and field work rather that lecturing history in the class. Restructuring topics in the syllabus is also noteworthy, but focus or emphasis can be done on the sub-topics. The number of discussion of current issues also need to be increased so that students are aware of the importance of their role towards the country and the surrounding community.

Thus, it is clearly shows that the Malay students need to understand and appreciate the values of the Nationalism and Contemporary Development in Malaysia courses in order to help them strengthen their national identity.

\section{References}

[1] Othman MY, Dakir J, Samian AL, Hasim MS, Awal NAM, Yahya SA, et al. JATI DIRI KEBANGSAAN DALAM KALANGAN PELAJAR INSTITUSI PENGAJIAN TINGGI (National Identity amongst Students of Higher Education Institutions). Jurnal Hadhari: An International Journal. 2012:67-78.

[2] McKenzie H. Citizenship education in Canada. Library of Parliament, Research Branch; 1993.

[3] Awang MM, Ahmad AR, Ghani SA, Yunus ANM, Ibrahim MAH, Ramalu JC, et al. Students' attitudes and their academic performance in nationhood education. International Education Studies. 2013;6(11):21.

[4] Isa K, Ani F. Perspektif mahasiswa Kejuruteraan Universiti Tun Hussein Onn Malaysia (UTHM) terhadap penubuhan gagasan Malaysia. Pembentukan Malaysia: Isu dan Cabaran. 2011:351-62.

[5] Adam MFM. Persepsi mahasiswa Universiti Putra Malaysia terhadap proses pembinaan negara-bangsa Malaysia: Universiti Putra Malaysia; 2002.

[6] Erdogan Y, Bayram S, Deniz L. Factors that influence academic achievement and attitudes in web based education. Online Submission. 2008;1(1):31-47.

[7] Ariffin K. The relationship between learning styles and academic achievements in the subject of Electromagnetic among fist degree students in UTHM. PSP's Research Digest. 2007:17-21.

[8] Awang MM, Jindal-Snape D, Barber T. A documentary analysis of the government's circulars on positive behavior enhancement strategies. Asian Social Science. 2013;9(5):203.

[9] Burbank H. German national identity: patriotism and stigma. Stanford undergraduate research journal. 2010(9):1. 